Moorbath, S. \& Pankhurst, R. J. 1976: Further rubidium-strontium age and isotope evidence for the nature of the late Archaean plutonic event in West Greenland. Nature, Lond. 262, 124-126.

Moorbath, S., Taylor, P. N. \& Goodwin, R. 1981: Origin of granitic magma by crustal remobilisation: $\mathrm{Rb}-\mathrm{Sr}$ and $\mathrm{Pb} / \mathrm{Pb}$ geochronology and isotope geochemistry of the late Archaean Qôrqut granite complex of southern West Greenland. Geochim. cosmochim. Acta 45, 1051-1060.

Taylor, P. N., Moorbath, S., Goodwin, R. \& Petrykowski, A. C. 1980: Crustal contamination as an indicator of the extent of early Archaean continental crust: $\mathrm{Pb}$ isotope evidence from the late $\mathrm{Ar}$ chaean gneisses of West Greenland. Geochim. cosmochim. Acta 44, 1437-1453.

Walton, B. J. 1976: Mapping of Archaean rocks in the inner Godthåbsfjord region, southern West Greenland. Rapp. Grønlands geol. Unders. 80, 72-77.

Department of Geology, The University, Exeter EX4 $4 Q E$, U.K.

\title{
Tungsten in the Godthåb area, West Greenland
}

\section{Peter W. Uitterdijk Appel}

The tungsten mineral scheelite has not previously been reported from the Godthåb area in West Greenland. The first indications of its presence were found in heavy mineral concentrates from a stream on Storø in Godthåbsfjord.

Exploration for scheelite in Greenland is difficult. A systematic stream-sediment programme cannot be undertaken before mid-June because many of the streams are frozen or covered with snow until then. Examination in ultra-violet light must be carried out in darkness so scheelite cannot be looked for before the end of August because of the midnight sun and the work must be finished by early September when snow covers the ground. A minor difficulty in this context is the abundance of lichens with bluish white fluorescence which cover the rock surfaces.

The following report is based on field observations only. Laboratory work was limited to $\mathrm{X}$-ray identification of scheelite in two heavy mineral concentrates and in two rock samples.

\section{General geology}

In the Godthåbsfjord area, several major rock forming events have taken place, the most important resulting in the formation of the Amîtsoq gneisses, the Nûk gneisses and the Qôrqut granite.

The Amîtsoq gneisses are the oldest, with isotopic ages of about 3700 m.y. (Black et al., 
1971). They are regarded as intrusive, and can be traced for more than $150 \mathrm{~km}$ from the Isukasia area north-east of Godthåb to the Buksefjorden area south of Godthåb. The gneisses are generally grey and homogeneous to banded. Inclusions of an older supracrustal belt, the so called Akilia inclusions, occur in the gneisses. The inclusions range in size from a few metres to many hundred metres, the largest being the Isua supracrustal belt which is more than $30 \mathrm{~km}$ long. The most important lithologies in the Isua supracrustals and in the Akilia inclusions are weakly banded amphibolites and horizons of banded iron formation, together with minor horizons of metasediments. The Akilia inclusions can be traced continuously from the Isukasia area to the Buksefjorden area, south of Godthåb. It is within these Akilia inclusions that scheelite mineralisation occurs.

The Nûk gneisses comprise banded to homogeneous quartzo-feldspatic intrusive gneisses (McGregor, 1973), formed about 3000 m.y. ago (Pankhurst et al., 1973). Extensive fragments of Malene supracrustal rocks and horizons of anorthosite occur enclosed within the Nûk gneisses.

The Amîtsoq and Nûk gneisses are distinguished in the field by the presence of Ameralik basic dykes in the former (McGregor, 1968). This dyke chronology is very useful, but it has its limitations since not all Amîtsoq gneisses have been intruded by Ameralik dykes.

The formation of the Qôrqut granite $2600 \mathrm{~m} . \mathrm{y}$. ago (Pankhurst et al., 1973) is the last major event in the Godthåbsfjord area. The granite is a polyphase intrusive granite, with abundant rafts and enclaves of the country gneisses (Brown \& Friend, 1979). One of the granite phases was derived by anatexis of Amîtsoq gneisses (Brown \& Friend, 1979). Abundant metre-wide coarse-grained quartz-feldspar-mica pegmatites are found associated with the Qôrqut granite.

\section{Sampling programme}

Stream-sediment samples were preferentially collected in streams close to rapids, where the sediments are coarse grained. Where possible, about 4 litres of sediment were collected, ranging in grainsize from fine sand to pebbles a few centimetres in size. The samples were sieved through a 6 mesh sieve and the coarse material, usually amounting to some 90 per cent of the sample, was discarded. The heavy minerals in the fine fraction were concentrated by panning. The concentrate was examined in ultra-violet light, and the scheelite grains were counted.

After the inital discovery of scheelite in a stream sediment on central Storø, a semi-regional sampling programme was launched. In this programme all major streams and most minor streams on the islands Storø, Sadelø and Bjørneøen, as well as in the Kobbefjord and south-east Godthåbsfjord areas, were sampled (fig. 18). Close to 100 stream sediments were collected and most of the results are shown in figure 18. The large gaps between some of the sampling sites are due to the presence of near vertical walls. In the inner part of Godthåbsfjord (north-east of fig. 18) a number of stream sediments were collected, many of which contained large quantities of scheelite grains.

Following the semi-regional sampling programme, a detailed follow-up stream sediment programme was carried out on central Storø, where about 40 samples were collected. In situ scheelite mineralisation was found as a result of this programme. This discovery was unfortunately made very late in the field season, so only a few nights of field work could be spent on the scheelite showings. 


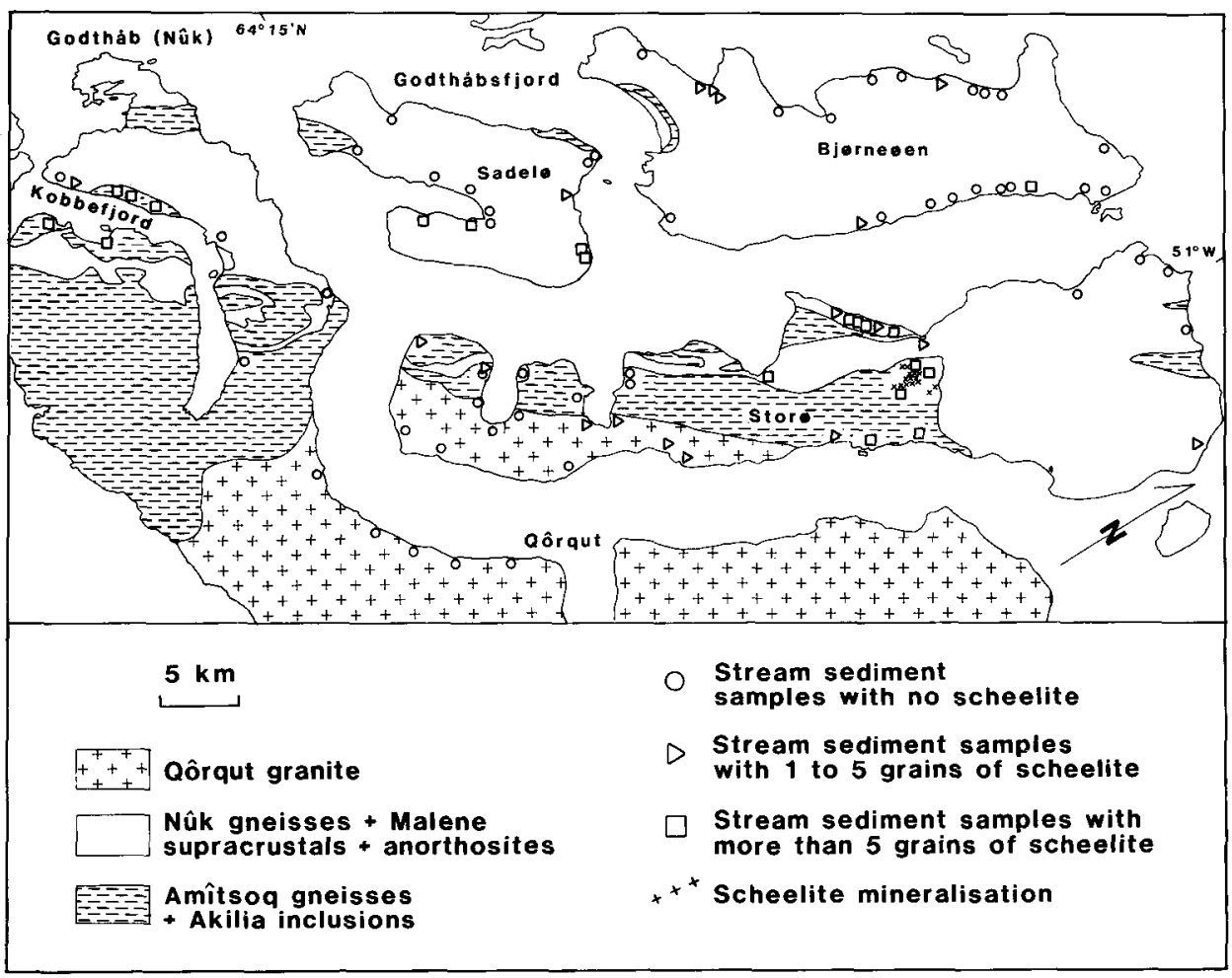

Fig. 18. Geological sketch map of the Godthåbsfjord area, showing sample sites for stream sediments and in situ scheelite mineralisation

\section{Scheelite mineralisation}

The stream-sediment sampling programme shows clearly that the majority of scheelite anomalies originate in areas where Amîtsoq gneisses occur. Nûk gneisses and Qôrqut granite contain apparently no scheelite. It is noteworthy that just one grain of scheelite in a stream sediment sample indicates that areas of scheelite mineralisation occur in the hinterland, since streams draining areas with Nûk gneisses and Qôrqut granite are barren. There are, however, a few exceptions. On Sadelø and Bjørneøen scheelite anomalies are found in areas where no Amîtsoq gneisses have been recorded. A likely explanation is that Amîtsoq gneisses are more extensive than the map indicates. In this context it must be borne in mind that the gneisses are quite similar in the field, the main distinguishing feature being the presence or absence of Ameralik dykes. It is thus possible that scheelite can be used to delineate areas with Amitsoq gneisses. The scheelite anomalies on south-east Storø in Qôrqut granite, can all be ascribed to Amîtsoq gneisses, since the streams originate in areas with Amîtsoq gneiss. 


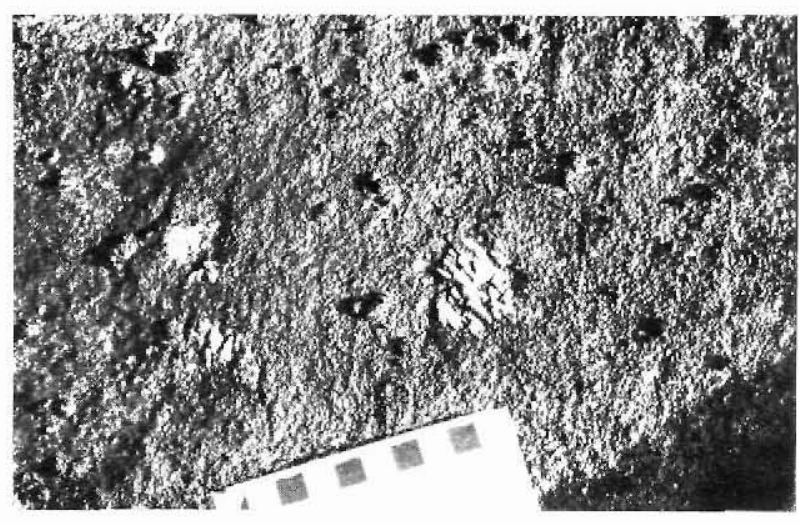

Fig. 19. Scheelite crystals on a joint surface in a grey supracrustal amphibolite.

The scheelite in the Amitsog gneisses has several modes of occurrence,

1. Scheelite in enclaves of supracrustal rocks (Akilia)

2. Scheelite in a discordant quartz vein

3. Scheelite in a gneiss boulder.

Most of the scheelite mineralisation found so far occurs in the Akilia supracrustals. Here, the most common host rock is a dark grey to black, weakly layered to bedded, amphibolite, where the scheelite occurs as tiny grains arranged parallel to the bedding or layering. This 'stratabound' type of scheelite mineralisation can be traced for several hundred metres. Thin scheelite-bearing mica schists are found associated with these amphibolites. Ultrabasic lenses are common in the Akilia inclusions. The outer parts of these lenses are frequently altered to a well lineated almost monomineralic, greenish, gedrite rock. In these gedrite rocks a peculiar type of scheelite mineralisation is found. It is a molybdenum-rich scheelite (see below) occurring as scattered grains and in tiny veinlets.

In the Amitsoq gneisses several isolated, up to $2 \mathrm{~m}$ wide, grey layered Akilia amphibolites with scheelite are found. Most of the scheelite in these amphibolites is found on joints, as thin coatings and as centimetre-size crystals (fig. 19). Scheelite-bearing joints are quite common in the amphibolites, but are never found to continue out into the host gneisses.

The Amîtsoq gneisses on central Storø are cut by numerous pegmatites, and veins of almost pure quartz. Many of these pegmatites and quartz veins have been scrutinized for scheelite in ultra-violet light, but only one about $20 \mathrm{~cm}$ wide quartz vein with a few grains of scheelite was found.

No scheelite has been found in situ in the Amitsoq gneisses. However, in a stream one boulder of grey gneiss with a few specks of scheelite was seen.

Field examination of scheelite in ultra-violet light showed that the scheelite apparently has a varying molybdenum content, depending on the host rock. This molybdenum content was determined by comparison with standards prepared by USGS. In the 'stratabound' type, the molybdenum content ranges from 0.05 to 0.24 per cent. Scheelite on joints in amphibolites contain 0.05 to 1.4 per cent molybdenum, whereas the scheelite in the gedrite-rich rocks contain 2.4 to more than 4.8 per cent molybdenum. 


\section{Discussion}

The regional distribution pattern of scheelite in stream sediments shows a clear correlation with the presence of Amîtsoq gneisses in the hinterland. The Nûk gneisses and the Qôrqut granite contain no scheelite. A tentative explanation of the few exceptions is that Amîtsoq gneisses may have been mistaken for Nûk gneisses on parts of Sadelø and Bjørneøen.

With the exception of one loose gneiss boulder and one thin quartz vein, all scheelite found so far occurs in Akilia supracrustals enclosed in Amitsoq gneisses. The biggest Akilia supracrustal enclave is the Isua supracrustal belt which is $30 \mathrm{~km}$ long. No attempt has so far been made to look for scheelite in this belt and the discovery of scheelite calls for a detailed investigation in this area. The present extent of scheelite anomalies is about $100 \mathrm{~km}$. If the Isua supracrustal belt is included, it will enlarge the area with possible scheelite mineralisations to more than $150 \mathrm{~km}$.

Whether a high-grade tungsten deposit occurs in the Godthåbsfjord area or not is of course highly speculative at the present time. However, the regional extent of scheelite indicates the possibility that high-grade deposits exist. Furthermore, the area has been metamorphosed at least twice, and has been intruded by the Qôrqut granite. Both the metamorphic events and the intrusive event have probably caused mobilisation, with subsequent concentration of scheelite, which could have resulted in the formation of high-grade ore bodies.

Acknowledgements. The author is grateful to Charlotte Clausen for her valuable asistance in the field, and to E. Leonardsen, Geological Institute, University of Copenhagen, for X-ray determination of the scheelite.

\section{References}

Black, L. P., Gale, N. H., Moorbath, S., Pankhurst, R. J. \& McGregor, V. R. 1971: Isotopic dating of very early Precambrian amphibolite facies gneisses from the Godthåb district, West Greenland. Earth planet. Sci. Lett. 12, 245--259.

Brown, M. \& Friend, C. R. L. 1979: The polyphase nature and internal structure of the Qôrqut Granite Complex east of Ũmánap suvdlua, Godthåbsfjord, southern West Greenland. Rapp. Grønlands geol. Unders. 100, 79-83.

McGregor, V. R. 1968: Field evidence of very old Precambrian rocks in the Godthåb area, West Greenland. Rapp. Grønlands geol. Unders. 15, 31-35.

McGregor, V. R. 1973: The early Precambrian gneisses of the Godthåb district, West Greenland. Phil. Trans. R. Soc. Lond. A 273, 343-358.

Pankhurst, R. J., Moorbath, S., Rex, D. C. \& Turner, G. 1973: Mineral age patterns in ca 3700 m.y. old rocks from West Greenland. Earth planet. Sci. Lett. 20, 157-170. 